\title{
Correction to Various Articles
}

Published online: 11 January 2022

(c) The Author(s) under exclusive licence to Sociedade Brasileira de Física 2021

\section{Correction to: Brazilian Journal of Physics https://doi.org/10.1007/s13538-021-00994-5 https://doi.org/10.1007/s13538-021-00995-4 https://doi.org/10.1007/s13538-021-00996-3 https://doi.org/10.1007/s13538-021-00997-2 https://doi.org/10.1007/s13538-021-00998-1 https://doi.org/10.1007/s13538-021-00999-0}

The copyright holder for these articles was incorrectly given as "The Author(s), under exclusive licence to The Author(s) under exclusive licence to Sociedade Brasileira de Física" but should have been "The Author(s) under exclusive licence to Sociedade Brasileira de Física."

The articles have been corrected.

Publisher's Note Springer Nature remains neutral with regard to jurisdictional claims in published maps and institutional affiliations.

The original articles can be found online at https://doi.org/10. 1007/s13538-021-00994-5, https://doi.org/10.1007/s13538-02100995-4, https://doi.org/10.1007/s13538-021-00996-3, https://doi. org/10.1007/s13538-021-00997-2, https://doi.org/10.1007/s13538021-00998-1 and https://doi.org/10.1007/s13538-021-00999-0. 